UDC 82-312.9.09

\title{
META-GENRE OF FANTASY IN THE CONTEXT \\ OF MODERN SCIENCE
}

\author{
Natalia Ivanova, \\ PhD in Philology, \\ Assistant Professor of School of the Russian Language, \\ World Literature and Methods of Teaching, \\ Bohdan Khmelnitsky National University, \\ Cherkasy, Ukraine, \\ e-mail: ivnathal@gmail.com \\ Olga Ryzhchenko, \\ PhD in Philology, \\ Assistant Professor of Language Training Department, \\ Kharkiv National University of Radio Electronics, \\ Kharkiv, Ukraine, \\ e-mail: eradis80@gmail.com
}

Received March, 12, 2019; Accepted May, 5, 2019

\begin{abstract}
The article deals with the problem of interpreting the phenomenon of fantasy in modern science. Fantasy has spawned many discussions related to the definition of its sources and genre nature, the relationship with the myth-folklore tradition, the problems of classification, the specifics of extraliterary functions and many others. We consider fantasy to be one of the branches of speculative fiction, which naturally formed into an independent industry in the second half of the twentieth century. Initially having appeared as a genre, fantasy subsequently has outgrown this category. Today we can say with confidence that fantasy is a meta-genre, which has its own structure of modeling the world and unites various literary genres (novel, novelette, lyric poetry and others) and types of art (sculpture, cinema, animation, graphic arts, painting, and others) with a common subject of artistic representation.

The constant dynamics of fantasy leads to the increase in the number of topics (heroic, epic, historical, magical, scientific, romantic and mystical) and, as a result, the readership as well. For example, it can be classified by age criterion (children - adult), by geographic criterion (urban countryside), and even by gender principle (men - women fantasy). There are several approaches presenting different aspects of the phenomenon: classifications by the type of adventure or problematicthematic principle (Ramin Shidfar or Sergey Alekseev and Mikhail Batshev). Such a diverse scientific interest in fantasy, multiple attempts to classify and systematize it, as well as going beyond the boundaries of the literary genre, testify to the ongoing process of its development.

Key words: classification, fantasy, meta-genre, mythology and folklore tradition, speculative fiction, themes and problems.
\end{abstract}

\section{Introduction}

Fantasy is a relatively new phenomenon in literature and it counts not more than fifty years. Experiencing a rapid development, it conquers not only many literary 
genres, but also penetrates into various forms of art. Consequently, fantasy relates to completely different subjects and on its basis it develops a fairly wide range of works. The latter, in turn, gives rise to an important theoretical classification problem of fantasy which still remains open.

Fantasy, standing out from speculative fiction into an independent genre, gradually expanded ideologically and thematically notionally. And today we can say for sure that fantasy has overgrown the concept of the literary genre by having won various forms of art (sculpture, painting, animation, cinema and others).

Olena Chernyavs'ka in the article To the Question of Defining of the Genre of Fantasy points out that such a dynamics of the phenomenon of fantasy, integrated into different spheres, requires constant research:

"At the end of the twentieth century - at the beginning of the 21st century fantasy takes up more and more stable positions, which can be explained both by sociocultural tendencies and specific literary peculiarities of this genre. National variants enrich and diversify the literature of fantasy, because the author's fantasy is not limited by a clear framework of the genre, or, as we can conclude, literary genres. Fantasy works may include elements of science fiction or other literary genres, so one can definitely say that the classification of fantasy must be thoroughly revised and constantly updated, since writers create new, original worlds and ways of displaying them in their writings every day" (Chernyavs'ka, 2015: 330).

This situation can be explained by the ongoing process of its development. However, we will try to present the situation in modern science in this article. Consequently, the purpose of our work is to analyze the researches of recent years which are devoted to the determining of the place and semantics of the phenomenon of fantasy in modern science. In particular, we offer our position regarding to the problem from the point of view of different spheres, as well as we formulate our definition of fantasy as meta-genre formation.

\section{Literature Review}

Fantasy, being a relatively new phenomenon in literature (it is not more than fifty years old), and experiencing a rapid development, has united researchers of completely different fields of knowledge around itself. Anna Grytting in her work On the Yellow Brick Road: Fantasy, Fairy Tales, and the Coming of Age Journey points out that today fantasy has proliferated from purely childish writing (that is, initially created as an entertaining children's fairy tale) to the literature satisfying the reader's interests of any age group (Grytting, 2018: 4-5).

Philologists argue about the genre nature, genesis, lexical-semantic filling of this phenomenon (Stephanie Dreier, Ekaterina Lugovaya, Tat'yana Markova, Valeriya Tolkacheva, Paula M. Zaja, Svitlana Lyevochkina, Oksana Marchuk). Psychologists talk about the causes of this type of work, associating it with a constant voltage and exaggeration (informational, mental) and the need to release emotions, fantasy in another world, fictional and successful. Philosophers seek 
the deep meaning of fantasy writing, projecting ideas into other areas of knowledge (Abigail Linhardt).

Originally fantasy was considered to be the literature of "other worlds" which can be monitored in the works by Aisling Byrne Otherworlds: Fantasy and History in Medieval Literature and Paula M. Zaja Beyond and Below: Subversive Spaces in Postmodern British Fantasy. Fantasy was associated with the supernatural (as it is analyzed in the work of Stephanie Dreier Old Fables and Their New Tricks: exploring revisionist fairytale fantasy in selected texts by Cornelia Funke and Svetlana Martynchik and Angelskår Svein Policing Fantasy: Problems of Genre in Fantasy Literature) or with the literature of escapism (presented by the work of Abbigail Mazour The Reality of Escape in Fantasy).

Thus, the study of Anastasia Demyna Fantasy in Modern Culture: a philosophical analysis is devoted to the philosophical analysis and understanding of fantasy as a phenomenon of modern culture. The researcher claims that by virtue of its mass character fantasy spreads into almost all spheres of human activity, forming a particular culture-forming field of the individual and influencing the development of society as a whole:

"Fantasy as a phenomenon of modern culture has inherited the nature of the simulation. Being a reflection of fantastic ideas and images, various fantasy products operate in the sociocultural space as simulacra. The tendency of fantasy to virtualization, as well as the nature of secondary reality, ontologically inherent in fantasy, allows us to speak about the evolution of fantasy as a third-order simulacra, according to the theory of J. Baudrillard" (Demyna, 2015: 20).

Since fantasy is a phenomenon actively developing in the second half of the 20-th the beginning of the 21-st century, most of the papers are devoted to the study of this phenomenon from the position of the philosophy of postmodernism. Fantasy is considered to be the emerging cultural phenomenon of the postmodernist era by Victor Pigulevsky in the monograph Irony and Fiction: From Romanticism to Postmodernism, as well as by the authors of a number of scientific works.

The sociological research of Fyodor Kosichkin proves the popularity of fantasy among different age groups, and above all among adolescents:

"According to the sales rankings, in the middle of the second decade of the $21^{\text {st }}$ century, the modern fairy tale - fantasy - is the main genre of middle and early teens literature" (Kosichkin, 2016).

The above is confirmed by the research made by Irina Sentemova, who claims that according to sociological research, every fifth book read by teenagers today is written in the fantasy genre (Sentemova, 2008).

It can be considered to be interesting a sociological study made by Olga Utkina, which was designed to reveal the basic reading preferences of boys and girls. So, the boys now mostly prefer "adventures, fantasy, funny stories, fairy tales, stories about animals <...> Favorite characters are Harry Potter, Vova Grushin, fairy-tale heroes" (Utkina, 2013: 253). While girls "prefer the following genres: fairy tales, poetry, novels, stories, children's detective stories, "horror stories", fantasy" (Utkina, 2012: 328). 
The conclusion is quite obvious: in early childhood, fairy tales have a tremendous influence on the development of the personality, which is subsequently reflected in the choice of literature for reading. The main message of both fairy tales and fantasy is that good must conquer evil, the hero is called to protect the weak, the wizard-hero alone can repel the enemy, which fosters patriotic feelings in children and also establishes moral values.

It is possible that the interest of the younger generation specifically to the works of fantasy is due to its roots in the fairy tale. Children learn to perceive the world around him through a fairy tale told in childhood. Hence, the cognitive and educational function of both fairy tales and fantasy works is obvious:

"The main myths that lie in the fairy tale are always the hero's journey behind his inner world, the Soul. Fairy tales always start from a state of rest: "Once upon a time". No matter how disturbed the peace is in a fairy tale. It is important that a person who absorbed fairy tales from his childhood keeps knowledge of how to act and overcome obstacles, how to grow up as a worthy person! <...> With the help of a fairy tale, in modern conditions, the magic method was born: "fairy tale therapy" (1982). The plot of fairy tales is built around a particular child" (Revenko, 2018: 176).

What is the reason for the popularity of fantasy among the younger generation? Fyodor Kosichkin sees it in the following: "books about dragons, princesses, magic manuscripts and spells are becoming more and more popular not because they lead away from reality, but because they bring it closer" (Kosichkin, 2016). And it is difficult to disagree with this statement, since the author justifies it as follows:

"Fantasy <> operates with universal categories of good and evil and exploits the discovery of archetypes. In a realistic story, especially in a school story, even the most notorious scoundrel and bastard is still polite and uses deodorant, otherwise it is simply impossible to imagine him in reality as a modern schoolchild from a developed country. In fantasy, the witch is a witch, with disheveled hair and a nasty smell, and a knight with a shining sword is exactly a knight with a sword" (Kosichkin, 2016).

Psychological studies of fantasy are somewhat similar to sociological ones: they are also aimed at studying the perception of works by various age and gender groups. However, the angle is fundamentally different, that is, they are interested in the mechanisms of perception and processing of information contained in fantasy, as well as how it can affect consciousness in the future.

In such a way, Marina Krivoruchko and Inna Alekseeva studying the influence of fantasy on the youth audience come to the conclusion that it has a twofold effect on the personality of the reader or viewer. On the one hand, it is positive as it lies in the fact that fantasy makes it possible to relieve tension quickly, get rid of stress, easily surviving the journey in time and space. The latter, according to the psychologists, allows you to create the effect of "canceling the past" with its failures and problems, encourages the reader or viewer to work, and also helps to find the meaning of existence (Krivoruchko and Alekseeva, 2017: 51). On the other 
hand, there is the effect of escapism, which acquires an ambiguous assessment in the circles of psychologists.

We believe that this perspective of research is quite promising. Attempts to attract young people to reading could be a worthy substitute for computer games. And we are sure that a departure from reality in reading is much more useful than uncontrolled games containing a large number of examples of cruel, asocial behavior, which often turn out to be veiled. Child and adolescent psyche is not always able to recognize it. In addition, it is well known that reading literature develops memory, speech, and literacy. It instills a variety of feelings: responsibility, patriotism, justice, and many others. They are brought up aesthetically. It is important to add to all this that fantasy, like games, allows to make a departure from the real not always prosperous world into the world of dreams and fantasy where the reader becomes a detached observer or participant of the events, who, in fact, will not be bothered by the problems of fictional worlds. However, some researchers see the problem of an informationally oversaturated society in escapism that needs emotional release (Elena Trufanova). One of the ways of such "escape from the reality" is to immerse yourself in reading fantasy.

"One can notice the characteristic feature of many popular "escapist" works - novels and films of fantasy genre. In many of them wide, deserted spaces are offered as the environment or the places of action because a modern person, especially a resident of a big city, gets too tired of the large number of people he constantly meets and the surrounding technosphere, and in escapism he seeks solitude, unity with nature or a small company of selected friends <...> However, for the escapist the main thing is not movement in space, but the changes in self-awareness and perception of reality that this movement causes. The only thing which is important is exactly what emotions, associations, images, impressions are arisen in connection with the new environment ..." (Trufanova, 2012: 104).

Brian Attebery makes similar comments regarding fantasy:

"Fantasy is a form of popular escapist literature that combines stock characters and devices - wizards, dragons, magic swords, and the likeinto a predictable plot in which the perennially understaffed forces of good triumph over a monolithic evil" (Attebery, 2004: 293).

However, escapism has a dual semantics. On the one hand, it can be used for psychocorrection and psychoanalysis. On the other hand, the excessive pursuit of escapism, even if it is fantasy reading, may indicate an acquired mental disorder or even autism.

Thus, we can conclude that despite the fact that fantasy is widely studied and interpreted, its inexorable dynamics generates more and more problems that need to be answered, for example, the problem of semantic field and genre nature. 


\section{Problems of defining the genre nature of fantasy}

Perhaps the greatest interest in fantasy is for literary studies, one of the important problems of which is the problem of terminology and the definition of genres. There is no single definition of this literary phenomenon, which proves the undying interest in fantasy. Most of the discussions are related to the formal content side of fantasy works.

For example, Tzvetan Todorov refers the works that contain a fantastic element to fantastic genres (historical and theoretical). Under "the fantastic" researcher understands:

"The hesitation experienced by a man who knows only the laws of nature when he observes a phenomenon that seems supernatural' (Todorov, 1999: 25).

In other words, Tzvetan Todorov understands the fantastic as some borderline between the unusual and the miraculous. However, the question here arises: "Who should doubt the truth of what is happening - the reader or the character?" Answering this question, the literary critic replies:

"The fantasy genre involves the integration of the reader into the world of characters, it is determined by the dual perception of the described events by the reader. It should immediately be clarified that, to put it this way, we do not mean a particular real reader but the reader's "function" implicit in the text" (Todorov, 1999: 30).

In such a way Stephanie Dreier defines fantasy fiction as:

"an independent literary genre with a distinct set of thematic and structural features, $<\ldots>$ comprised of narratives in which the violation of natural laws, otherwise known as the supernatural component, is indispensable to the integrity of the narrative" (Dreier, 2018: 26).

While Paula M. Zaja examines fantasy through the mirror of postmodernism defining it as

"a mode of writing which uses imagination and metaphor to revise reality in a way that reflects and confronts what we experience in our daily lives" (Paula M. Zaja, 2018: 1).

Sergey Galiev, having studied many definitions of fantasy, structures them into three groups:

1. The most numerous group, represented by encyclopedias and literary dictionaries, classifies fantasy as a special kind of Magic Fairy Tale.

2. The group represents the opinion of researchers who base the definition of fantasy on vague notions of the supernatural, the irrational and the inexplicable.

3. The group defines fantasy as complex synthetic genre constructions, such as "a fantastic philosophical novel with elements of a fairy tale and a heroic epic" or 
"a modern heroic-mythological epic created in the traditions of northern mythology" (Galiev, 2010).

However, the author himself defines this phenomenon through the prism of fairy-tale prose, pointing out that in many ways fantasy repeats and, most importantly, goes back to a fairy tale.

As a rule, most definitions report to the genre. We offer to define fantasy more broadly as a meta-genre, all the more so since there are good reasons for it as it has its own stable structure of modeling the world and brings together a diverse array of genres in literature and other arts as a common object of artistic representation. And the fact that fantasy has retained its structural-semantic core for several eras (which is an important feature of the meta-genre) is indicated by the presence of fantasy elements in modernism and literature of earlier eras (we are talking about fantasy as a meta-genre in detail in our article Fantasy semantic field: problems of definition, filed in Karazin University Journal of Philology). For example, William Shakespeare A Midsummer Night's Dream, Mark Twain A Connecticut Yankee in King Arthur's Court, Edgar Rice Burroughs John Carter of Mars series, Alexandre Dumas The Three Musketeers, Nikolay Gogol Viy, Gerhart Hauptmann Hanneles Himmelfahrt, Maurice Maeterlinck The Blue Bird, Mikhail Bulgakov The Master and Margarita, Fedor Sologub Dog, Saddened Bride, Red-lipped guest and others.

The latter gives us the reason to assert that it is better to refer fantasy to the meta-genre. We believe that it as one of the branches of speculative fiction appeared first in the framework of literary epic, and subsequently conquers other literary genres and types of art. This is fully consistent with the definition of the meta-genre proposed by Rita Spivak in the monograph Russian Philosophical Lyrics: the Problem of the Typology of Genres, where it is proposed to consider the meta-genre as:

" a structurally expressed, neutral in relation to the genus, a stable invariant of many historically specific means of artistic modeling of the world, united by a common subject of artistic representation" (Spivak, 1985: 53).

Consequently, at first, a certain supergenre structural-semantic core was formed, that is, structural principles for the construction of the artistic world, which makes it possible to combine the works into a fantasy "union". Naum Leiderman called this phenomenon "senior genre", which originates in the framework of a literary movement or trend, and subsequently extends to more distant genres:

"If we are talking about the genre community, then we should look for the grounds for their contraction in the "nest" ("family") precisely in the typologically related genre-forming principles, that is, the principles of the creation of the world-image" (Leiderman, 2010: 328).

These principles of the world building, in our opinion, include the re-creation of a nonexistent impossible world where heroes and their antagonists necessarily operate with the use of magical objects to achieve their goal under the opposition to the evil on a global scale, etc. These elements are common to all kinds of fantasy. Moreover, in spite of the complexity, deep psychology and the philosophical nature of the images, there is a certain typification in them similar to that in the fairy tale or 
in the classicist works. It is primarily about the determination of characters as a good or evil beginning, the recurrence of certain plot forms. However, such a typicality in the creation of fantasy works does not detract from the originality and artistic value of each work. Up to date, a number of issues related to determining the place of fantasy in modern literature and art in general, its genres and classification, its functions in modern society and many others remain relevant.

\section{Fantasy sources}

Studying the genesis of genres, artistic devices or other literary phenomena is one of the key tasks of historical poetics. However, an important problem concerning the nature of the young phenomenon of fantasy has not been solved up to date and has generated a large number of discussions. Some researchers call it the source of the myth, claiming that fantasy is built according to the principles of the mythological world order. However, fantasy as a literary work, according to the predominant number of definitions, creates an artistic world that is fictional. The myth is oriented to reality: it is the first cognitive system of the archaic man. According to Mircea Eliade, it is a sacred story that represents the real event:

\section{"the myth expounds a sacred story, tells the story of an event that occurred in memorable times, "the beginning of all beginnings". The myth historifies how the reality, thanks to the exploits of supernatural beings, has achieved its embodiment and realization, be it an all-encompassing reality, the cosmos, or just a fragment of it" (Eliade, 1996: 15).}

In addition, the myth is devoid of poetry for various reasons (Yuryi Lotman and Boris Uspenskij wrote about it in their article Myth - name - culture (Lotman and Uspenskij, 1992: 72-73)). Myth acquired poetic design only in folklore. This means that only through folklore myth penetrates into literature. Another source of fantasy is called the oral-poetic tradition, especially the genre of the fairy tale. Several researchers define them as fairy tales, since they are dedicated to fictional, non-existent worlds, characters, phenomena. This is not entirely correct, since the fairy tale has developed its structure and a steady sequence of actions: it never changes the position, the development of the action, the climax and the denouement (see Vladimir Propp Morphology of the Folktale). In literature this was possible only in classic drama. In general, literature strives for creative freedom, and fantasy is not an exception. It should also be noted that artistic devices in the fairy tale are usually stable, and their originality is valued in literature.

However, there are still some fairy-tale effects in fantasy. For example, the obligatory presence of the hero and his antagonist who are in opposition to the good-evil: Gandalf and Saruman (The Lord of the Rings trilogy), Harry Potter and Lord Voldemort (The Harry Potter series), people and White Walkers (The Song of Ice and Fire series). Moreover, magical events and heroes are preferable. Likewise, Ukrainian writers Maryna and Serhiy Dyachenko provide descriptions of magical creatures in their novel Bastard.

Zazhora is a magical trap which attracts wanderers with child's screaming: 
"Stanko's pupils dilated. At the bottom of the crater, a round black hole was found, it was the center of a hurricane, branches of bushes and surrounding trees stretched to it, tortured by the wind, and with its inexorable force attracted Stanko, the protector of children.

- Help! - a sound thinly came straight from the hole, the cry turned into a mocking gurgle, and Stanko, disbelieving his eyes, saw black lips framing the hole - thin, wrinkled, like pedes.

He went astray, just like a bug, which was visiting an ant lion. Like a bug, he was weak and helpless; like a little bug, he was striving for strength upward and crawled downward, drawn in, absorbed, drawn in. Good spirits, what the sword for?

- "Zazhora"! This is a "zazhora"! - forgotten Elijash was exerting himself to the utmost somewhere upstairs.

The mouth seems to grin. Broken leaves, mosquito flocks, gapered birds were brought by the wind into the womb... Stanko was a desired treat, an exquisite dish on this scanty table, it seemed to him that he saw muddy drops of greedy saliva on its black lips" (Dyachenko, 2008: 65).

One more example of a magical trap is Zheltomara:

"The black face with a pipe in his mouth seemed peaceful, even goodnatured. No breeze, no whiff. Stanko blinked in surprise and at that moment a little cloud of smoke flew out of the aquiline-nosed old man's pipe.

Stanko opened his mouth. The smoke was of a dirty yellow colour, the cloud did not dissolve as it usually did but hanging still sank into a dense cloud.

"Zheltomara" Elijash whispered in anguish. "Zheltomara", that's what it is!

The cloud hung motionless. A couple of magpies flashed through with a crick-crack, a cloud arched idly, catching one of them with an edge.

Stanko did not know that a bird could scream like that. Feathers showered; the second magpie swept over the shapeless ball, which, twitching, fell into the stones and disappeared from sight. The scream fell" (Dyachenko, 2008: 78).

The goals of the heroes in fantasy plots, as well as in the fairy tale, are achieved with the help or for the sake of magical objects (artifacts). For example, in the cycle Watch by Sergey Lukyanenko one can single out an entire arsenal of such: the Crown of All (stones at the base of Edinburgh castle, with which you can set free the Others, giving them death), "Fuaran" (the book that contains spells how to turn a man into the Other), Schrödinger's Cat (a fur ribbon that was worn by the escorted criminal, obtaining the ability to behead him at the slightest attempt to use magic), the Chalk of Fate (a piece of chalk, with the help of which you can change the fate of any person or the Other), Minoan Sphere (opens any portal), Prism of Power (with its help you can draw vitality from anyone who looks at it through it). In addition, Others, even weak, could create strong enough amulets by long work by casting spells.

Ordeals that happen to fairy-tale heroes, as a rule, radically change them. This is a kind of initiation rite, revealing an incredible physical, spiritual, and intellectual power in them. Similar changes are happening to fantasy characters.

However, to say that exclusively the myth-folk tradition is the basis of fantasy is not quite fair. Since many images, ideas, motifs of literatures of different eras 
were borrowed and rethought by it. Like images of mysterious castles, notions of honor and dishonor, knightly duty were borrowed from Medieval literature.

For example, Hogwarts School of Witchcraft and Wizardry in the series about Harry Potter by Joanne Rowling:

"The narrow path had opened suddenly onto the edge of a great black take.

Perched atop a high mountain on the other side, its windows sparkling in the starry sky, was a vast castle with many turrets and towers. $<\ldots>$ They were carried along a dark tunnel, which seemed to be taking them right underneath the castle, until they reached a kind of underground harbor, where they clambered out onto rocks and pebbles" (Rowling, 2010: 140-141).

One more vivid example is the description of Seven Kingdoms from the first part of the series The Song of Ice and Fire by George Martin:

"Somewhere beyond the sunset, across the narrow sea, lay a land of green hills and flowered plains and great rushing rivers, where towers of dark stone rose amidst magnificent blue-grey mountains, and armored knights rode to battle beneath the banners of their lords. The Dothraki called that land Rhaesh Andahli, the land of the Andals. In the Free Cities, they talked of Westerosand the Sunset Kingdoms" (Martin, 2011: 58).

Romantics will give interest to everything exotic, mystical, fantastic, which goes back to the myth-folk tradition. Exceptional characters act in exceptional events (like ordinary boy Harry Potter who survived the meeting with the Death).

Scientific and technological progress has contributed to the development of fantasy as well.

However, we see that recently the format of this meta-genre is expanding, complemented by new themes, types of characters, some new places. This situation allows us to talk about a sufficient variety of fantasy types to conduct its classification.

\section{Fantasy genre varieties and their classification}

Up to date, there is a fairly large number of diverse classifications of fantasy, which take one or another element of the genre as a basic one. In such a way in his work Genre Classification of Contemporary Russian Fantasy: Setting up the Problem Ivan Lebedev points out that there are several approaches to the classification of fantasy. The first approach involves the classification of fantasy by the type of adventure, since "in any fantasy work, an adventure rather than fantasy component comes to the fore" (Lebedev, 2015: 57).

Following this path, you can come to the conclusion that fantasy is a special subtype of adventure literature, which is not quite true. In our opinion, adventure intrigue is one of the components of fantasy (which we highlighted in our work on the definition of fantasy (Ryzhchenko, 2018)). In this regard, it will be fair to point out that the choice of adventure intrigue is determined by the specifics of the genre.

Most classifications are based on the problematic-thematic principle. Likewise Ramin Shidfar distinguishes the following types (Afanas'eva, 2009: 87): 
- heroic (or epic) fantasy (where works are based on Celtic folklore);

John Ronald Reuel Tolkien (The Lord of the Rings), Stephen R. Donaldson (The Chronicles of Thomas Covenant);

- folklore and fairy-tale, "where the characters live in the real world, populated by characters from myths";

Sergey Lukyanenko (Night watch), Maryna and Serhiy Dyachenko (Age of Witches);

- fantasy of "sword and magic" (it can be called a heroic-epic and adventurous fantasy);

Hisago Amazake (series of light novels of Japanese Knight and Magic);

- myth-forming, where "a world with its own mythology is created";

Roger Lancelyn (Green Tales of the Greek Heroes), Marion Zimmer Bradley (The Mists of Avalon), Juliet Marillier (Wildwood Dancing), Margaret Atwood (Penelopiad).

From our point of view, thematic variety of fantasy works can't be limited just by four positions as nowadays we face quite a popular urban fantasy or a variety of different split genre works like fantasy detective or horror. Thus thematic classification must contain the whole range of thematic fantasy groups.

One more attempt to choose thematic principle for classification was made by Sergey Alekseev and Mikhail Batshev who define:

- "classical fantasy", where "the action takes place in some conditional mythical past, in our world or in parallel reality";

Thomas Burnett Swann (Day of the Minotaur), Lesley What (Olympic Games);

- historical fantasy;

Maurice Druon (The Memoirs of Zeus), James Gawley (Exiles of Arcadia);

- scientific fantasy, connecting science fiction with fantastic assumptions;

Sviatoslav Loginov (The Guard of the Pass), Poul Anderson (Operation series) (Alekseev, Batshev, 1997: 83).

The authors take historical point of reference as the basis for their classification placing the events in the "imaginary past" or "assumed future" that is not quite reasonable as it is not quite clear if we have a deal with "pure fantasy" or anti-utopia.

Elena Afanas'eva opposes Elena Kovtun in the article Fantasy Genre: The Problem of Classification. Elena Kovtun identifies 4 types of fantasy based on the problematic-thematic principle:

- mystic-philosophical fantasy;

- metaphorical fantasy;

- "black" fantasy;

- heroic fantasy (Afanas'eva, 2009).

Such a classification is not complete, since it does not take into account the whole wide thematic spectrum, which allows creating works of fantasy on the verge of other genres, be it a psychological novel (works by Maryna and Serhiy Dyachenko, in particular The Valley of Conscience), or historical fantasy (novel by Boris Akunin Children's bookfor boys from the series Genres).

Elena Afanas'eva provides her own classification of fantasy:

- on the basis of the plot;

epic;

romantic: Elena Haetskaya (Anahron), Daliya Trusnikovskaya (Royal blood), Victoria Ugrumova (The name of the goddess); 
Reality);

mystical: Sergey Lukyanenko (Night Watch), Vasiliy Golovachev (Forbidden

"black": Andrey Dashkov (Wandering of Senor);

"mythological": Henry Lion Oldie (The Hero must be Alone),

Andriy Valentinov (Diomedes, the Son of Tydeus);

- on the basis of the national specifics;

Celtic, Mongolian, Scandinavian, Slavonic, etc.: Sviatoslav Loginov (Multiarmed god dalaina), Maria Semenova (Wolfhound);

- on the basis of the the time of the action;

historical and pseudohistorical fantasy: Andrey Valentinov (Ola);

urban (modern) fantasy: Sergey Lukyanenko (Night Watch), Mikhail Bulgakov (The Master and Margarita);

fantasy about the distant future;

- on the basis of the axiological aspect;

heroic fantasy with the most positive evaluation;

"satirical" fantasy, denying the heroic, humorous: Max Frei (The Labyrinths of Echo), Michael Uspensky (The Adventure of Zhihar);

- on the basis of the worldview aspect;

Christian or sacred fantasy: John Milton (Paradise Lost), Elena Haetskaya (The Obscurantist);

techno-magic (scientific fantasy);

philosophical thriller;

- on the basis of the addressee;

adult;

children: Kir Bulychev The Pass (Afanas'eva, 2009).

This classification seems to cover all the necessary aspects of fantasy taking into consideration almost all the features of the genre. We believe that this classification can be considered to be the fullest up to date.

Marie-Charlotte Damasco says that today fantasy begins to acquire clear boundaries that distinguish it from other schools of speculative fiction (like horror or merveilleux). The researcher distinguishes two classifications. Following Anne Berthelot, fantasy is classified into three large thematic groups:

- high fantasy which depicts Medieval world with heroic warriors or magicians;

Terry Pratchett (Discworls series), Vladislav Rusanov (Hot Winds of North trilogy, Blades of Boundaries series and Dragons Slayer series), Andrzej Sapkowski (Witcher Saga), Maria Semyonova (Wolfhound series);

- dark fantasy with the domination of the themes close to horrors;

Stephen King (The Dark Tower series), Peter Straub (Shadowland), Clive Barker (Weaveworld), Raymond Feist (Faerie Tale);

- urban fantasy which describes the coexistence of hybrid creatures (for example, vampires or werewolves) forming their own microcosm;

Sergey Lukyanenko (Night Watch series), Ben Aaronovitch (Rivers of London series), Terry Brooks (Word \& Void series).

In the classification by Jacques Goimard fantasy is divided into:

- heroic fantasy where the hero not possessing supernatural forces opposes the world of evil;

Robert E. Howard (stories about Conan the Barbarian), L. Ron Hubbard (Slaves of Sleep); 
- high fantasy where the heroes and their allies perform the task, using hidden opportunities in the ethical dimension;

Roger Zelazny (The Chronicles of Amber), Ursula K. Le Guin (Earthsea), John Ronald Reuel Tolkien (The Hobbit, The Lord of the Rings);

- low fantasy which covers the world of people and elves; trilogy);

Philip Mazza (The Harrow Saga), Tad Williams (Memory, Sorrow, and Thorn

- science fantasy which depicts the future with unforeseen phenomena, impressive superpowers, where nothing is impossible, especially in terms of unseen beings;

Keith Roberts (Pavane), Sviatoslav Loginov (the Guard of the Pass);

- romantic fantasy which has a reputation of male literature where the main characters are women, warriors and wizards, their life full of adventures and quests;

Mercedes Lackey (Tales of the Five Hundred Kingdoms), Tamora Pierce (The Immortal quartet);

- light fantasy where the characters are children, monsters, different worlds with a touch of humor, the action takes place in funny countries;

Joanne Rowling (Harry Potter series), Philip Pullman (The Golden Compass), Neil Gailman (Neverwhere) (Damasco, 2016).

As Ivan Lebedev (Lebedev, 2015) aptly notes all abovementioned classifications have some faults and they can't be taken as incontestable and exclusively right. So the problem of classification is about to be solved. But some additional approaches can be suggested accordingly. We agree with the researcher as it can be seen from the given classifications that they all have some common root.

\section{Conclusion}

Fantasy as a relatively young literary phenomenon today is the focus of many sciences: philosophy, psychology, sociology, philology. However, it has not yet acquired a clear definition. It is called the type, type of literature, genre, genre variety. With confidence we can say that today fantasy has grown into a genre category. We define it as a meta-genre, which has its own structure for modeling the world and unites various not only literary genres (novel, novelette, lyrics, and others) as a common subject of artistic representation, but also arts (sculpture, cinema, animation, graphic arts, painting, and others). The main source of fantasy is the myth-folk tradition, however, it has gained a lot from literatures of different eras (Medieval royal chivalry, baroque, gothic romance, romantic and modernist poetics of the fantastic). The presence of a large number of attempts to classify this phenomenon indicates the constant dynamics of fantasy, as well as the prospects of this kind of research.

\section{References}

Afanas'eva, Elena. 2009. “Zhanr fehntezi: problema klassifikacii.” Fantastika i tekhnologii (pamyati Stanislava Lema) 86-93.

Alekseev, Sergey and Mikhail, Batshev. 1997. "Fehntezi - razvitie zhanra v Rossii." Knizhnoe delo 1:82-86. 
Angelskar, Svein. 2005. Policing Fantasy: Problems of Genre in Fantasy Literature. Master's thesis. The University of Oslo. http://urn.nb.no/URN:NBN:no12249

Attebery, Brian. 2004. "Fantasy as Mode, Genre, Formula." In Fantastic Literature: A Critical Reader, edited by David Sandner, 293-309. Praeger: Westport, Connecticut London.

Byrne, Aisling. 2016. Otherworlds: Fantasy and History in Medieval Literature. Oxford: Oxford University Press.

Chernyavs'ka, Olena. 2015. "Do pytannya klasyfikaciyi zhanru fentezi." Literaturoznavchi studiyi 1(2):323-331. http://nbuv.gov.ua/UJRN/ Lits_2015_1\%282\%29_38

Damasco, Marie-Charlotte. 2016. "Un regard sur la fantasy en France." Monde du livre. https://mondedulivre.hypotheses.org/5248

Demyna, Anastasia. 2015. Fantasy in Modern Culture: a philosophical analysis. PhD diss., University of Astrakhan.

Dreier, Stephanie. 2018. Old fables and their new tricks: exploring revisionist fairytale fantasy in selected texts by Cornelia Funke and Svetlana Martynchik. PhD diss., Vancouver: the University of British Columbia.

Dyachenko, Maryna and Dyachenko, Serhiy. 2008. Bastard. Moskva: Eksmo.

Eliade, Mircea. 1996. Aspects du Mythe. Translated by Viktoriya Bol'shakova. Moskva: Invest-PPP, ST “PPP”.

Galiev, Sergey. 2010. "Klassifikaciya zhanra fehntezi. Proizvedenija Dzh. R. R. Tolkijena." Andreevskyje Chtenyja. Literatura XX veka: itogi $i$ perspektivy izucheniia, 2010. Accessed August 13, 2011. https://www.proza.ru/ $\underline{2011 / 08 / 13 / 1098}$

Grytting, Anna. 2018. On the Yellow Brick Road: Fantasy, Fairy Tales, and the Coming of Age Journey. Master's thesis. University of Agder. http://hdl.handle.net/ $11250 / 2562922$

Kosychkin, Fyodor. 2016. "Nastoyaschee fenhtezi." God literatury, April 13. https://godliteratury.ru/public-post/nastoyashhee-fyentezi

Krivoruchko, Marina and Alekseeva, Inna. 2017. "Sotsyalnopsykholohycheskye osobennosty i tipy molodezhnoi audytory s razlychnoi stepeniu uvlechennosty filmamy y seryalamy v zhanre fentezy." Vestnyk Omskoho unyversyteta. Seryia "Psykholohyia" 2:49-58.

Lebedev, Ivan. 2015. "Genre Classification of Contemporary Russian Fantasy: Setting up the Problem." Mezhdunarodnyi nauchnyi zhurnal "Innovatsionnaya nauka" 7:56-58.

Leiderman, Naum. 2010. Teoriya zhanra. Ekaterinburg: Institut filologicheskih issledovanij i obrazovatelnyh strategii "Slovesnik" UrO RAO; UrGPU.

Linhardt, Abigail. 2016. Rhetorically Fantastic: The Relationship Between Fantasy Literature and Academic Scholarship As Seen Through an Analysis Of The Neverending Story. $\mathrm{PhD}$ diss., University of Findlay.

Lotman, Yuryi and Uspenskii, Boris. 1992. "Mif - imya - kultura.” Izbrannye stati $v$ trekh tomah 1:58-75.

Lugovaya, Ekaterina. 2015. "Mifopoehticheskie osnovaniya proizvedenii zhanra fantasy." Gumanitarnye i yuridicheskie issledovaniya 76-79. 
Markova, Tatiana. 2017. "Zhanrovaya priroda romanov M. Semenovoi." Vestnik Chelyabinskogo gosudarstvennogo pedagogicheskogo universiteta 8:152-156.

Martin, George R. R. 2011. Game of Thrones. Bantam; Media Tie In, Reprint edition.

Mazour, Abbigail. 2018. "The Reality of Escape in Fantasy." Honors Theses, University of Nebraska-Lincoln. https://digitalcommons.unl.edu/ honorstheses/54/

Pigulevsky, Victor. 2003. Irony and Fiction: From Romanticism to Postmodernism. Rostov-na-Donu: Foliant.

Propp, Vladimir. 2009. Morphology of the Folktale. Translated by Laurence Scott. Austin: University of Texas Press.

Revenko, Nina. 2018. "Mir skazki' cherez pokoleniya." Gumanitarnyie vedomosiy TGPU im. L. N. Tolstogo 3(27):1, 173-177.

Rowling, Joanne. 2017. Harry Potter and the Philosopher's Stone. London: Bloomsbury.

Ryzhchenko, Olga. 2018. "Problems of definition and classification of fantasy: Western European and Slavonic perspectives." SHS Web of Conferences 55:04009. Accessed November 14, 2018. doi.org/10.1051/shsconf/20185504009

Sentemova, Irina. 2008. "Fentezy." Otkrytyi urok. Pervoe sentiabria, February $\quad 14 . \quad$ http://xn-i1abbnckbmcl9fb.xn-p1ai/\%D1\%81\%D1\%82\%D0\% B0\%D1\%82\%D1\%8C\%D0\%B8/506375/

Spivak, Rita. 1985. Russkaya filosofskaya lirika: problemy tipologii zhanrov. Krasnoyarsk: Izdatelstvo Krasnoyarskogo universiteta.

Todorov, Tzvetan. 1999. Introduction to the fantastic literature. Translated by Boris Narumov. Moskva: Dom intellektualnoi knigi.

Tolkacheva, Valeriya. 2010. "Fehntezi: zhanr ili literaturnoe napravlenie?" Izvestiya Volgogradskogo Gosudarstvennogo Pedagogicheskogo universiteta 169-172.

Trufanova, Elena. 2012. "Eskapyzm i eskapistskoe soznaniye: k opredeleniyu poniatii." Filosofiya i kultura 3:96-107.

Utkina, Olga. 2012. "Hendernyi aspekt $\mathrm{v}$ detskoi literature: chto chitayut devochki?" Vestnyk KHPU im. V.P. Astafeva. Fylolohyia 328-331.

Utkina, Olga. 2013. "Hendernyi aspekt v detskoi literature: chto chytayut malchiki?" Pedahohycheskoe obrazovanye v Rossyy 6: 252-256.

Zaja, Paula M. 2018. Beyond and Below: Subversive Spaces in Postmodern British Fantasy. Master's thesis. Purdue University. https://docs.lib.purdue.edu/ dissertations/AAI10811659/ 